\title{
Online Banking System-Its Application in Some Selected Private Commercial Banks in Bangladesh
}

\author{
Muhammad Abdus Sattar Titu ${ }^{1}$, Md. Azizur Rahman ${ }^{2}$ \\ ${ }^{I}$ Faculty of Science and Technology, Atish Dipankar University of Science and Technology (Main Campus), \\ Bangladesh. \\ ${ }^{2}$ Department of Business Administration, International Islamic University Chittagong, Dhaka, Bangladesh.
}

\begin{abstract}
The outcome of the study is based on both the primary and secondary data and information. The primary data were collected from a total number of 50 customers (25 big and 25 mid level customers) from 10 Private Commercial Banks (PCBs). Again, a total number of 50 bankers taking 5 from each sample banks were also selected as the respondents. Both the banks and customers were selected using convenient sampling for easy and smooth collection of data and information. Two sets of structured questionnaire keeping in line with the objectives were prepared for collecting the requisite data. The main research issues covered in the study are: adoption of online banking facilities in Bangladesh, identifying major components of online banking and their application, knowing the main online banking services offered by the selected banks, assessing customer satisfaction on online banking service and identifying the major problems of online banking service in selected banks. The main findings of the study are: i) it is observed that OBS has been introduced in Bangladesh in 1998. Up to December, 2011 OBS has in operation in a total number of 47 banks out of 56 banks. It is reported that fully OBS has been in operation in almost all foreign commercial banks. In all the $2^{\text {nd }}$ and $3^{\text {rd }}$ generation banks of local commercial banks OBS has been in full operation. In case of all $1^{\text {st }}$ generation banks and some $2^{\text {nd }}$ generation banks have introduced partial OBS.(ii) in most of the selected banks, the components namely debit card, credit card, automated teller machine such as Master Card, Visa Card, Q-cash Card, Point of sales, on line service, internet Banking and society for worldwide interbank financial telecommunication etc. have been introduced up to December 2011. (iii) the major online banking services are offered have been: View statements and account balances, Fund transfers, Bill payment, Manage savings and current account, Card service, Order cheque and books request, Stopping cheque, Fixed deposit placement and Requesting the bank statement. iv) on the basis of five point Likert scale, it is found that 60\% of the customers have been highly satisfied, $24 \%$ of the customers have been satisfied and the remaining $16 \%$ of the customers have been unsatisfied on the online banking services offered by selected banks. As regards the impact of OBS on the customers, the study reveals that OBS reduces the frequency of customers' physical visits to the banks, customers are getting substantial benefits, customers are secured and customers access to accounts round the clock etc. v) the selected customers have identified some major problems of OBS such as unavailability of a backbone network connecting the whole country, inadequacy of reliable and secured information infrastructure especially in telecommunication infrastructure; sluggish ICT penetration in banking sector; insufficient legal and regulatory support for adopting e-banking; negative attitudes of management; lack of IT resources; lack of knowledge among employees and customers etc. The information generated in the study and its findings may be useful to the researchers, academicians, bankers and policy makers. The academicians interested for further research in this demanding area of the banks may get the findings useful. Again, bankers may also come across the findings of the study while performing their banking jobs for the full satisfaction of the customers. Lastly, the government and policy makers may also use the outcomes of the study while formulating any policy as regards OBS.
\end{abstract}

Key Words- Online Banking System, Private Commercial Bank, Debit \& Credit card, ATM, and SWIFT.

\section{Introduction}

In today's world of emerging technologies, enterprises are moving towards the Internet for businesses. People are rushing towards the e-commerce applications for their day-today needs, which in turn are making the Internet very popular. Online Banking has given both an opportunity and a challenge to traditional banking. In the fast growing world, banking is a necessity, which in turn takes a lot of time from our busy schedule. Going to a branch or ATM or paying bills by paper check and mailing them out, and balancing checkbooks are all time-consuming tasks. Banking online automates many of these processes, saving time and money. For all banks, online banking is a powerful tool to gain new customers while it helps to eliminates costly paper handling and manual teller interactions in an increasingly competitive banking environment. Banks have spent generations gaining trust of their customers.

It is now widely accepted that the information technology revolution will have a profound effect on the conduct of 'how business will be done' as we move towards the new millennium. One of the most important 
developments, in this respect, has been the explosion of Internet banking activity on the Internet. With connectivity growing at an average of 10 per cent per month, Internet proof to offer commercial business with more opportunities. A recent study by IBM predicted 500 million active users by the year 2000 (Financial Times, 1996 as cited in Hamill, 1997). Furthermore, the conservative estimates suggest 200-300 million users by the turn of the century (Hamill, 1997). The Internet can no longer be considered a "fad" or the preserve of "techies" and "computer nerds". Commercial uses of the Net have become the fastest growing part of the World Wide Web (WWW). As far as Internet banking is concerned, banking institutions in both countries notably in Malaysia and Thailand will be able to increase their competitiveness since Internet banking can be a powerful source of competitive advantage in penetrating more profitable consumers.

Inevitability, Internet banking will continue to revolutionize the current traditional banking industry and offers more opportunity to meet better consumer services through enhanced interaction, data mining and customization in the Internet banking services. the Internet Banking System widely used and the banks looking to provide the best quality system with highly available, fast response, secure and safe to use (Alanazi et al 2010)

First introduced in the early 1980s (Kalakota and Whinston, 1997), online banking provides its consumers with an application software program that operates on personal computer (PC) which can be dialed into the bank via a modem, telephone line and operated the programs remotely on the consumer PC. Information technology (IT) was primarily employed to automate the back-office (core process and support process) of banks in 1960s. Nonetheless, enhanced technology was deployed to extend the back-office to the front office (integrated system). This extension helps to enable the banking industry to offer their services via the Internet.

With respect to internet banking, a common confusion exists between the term of online banking, Internet banking as well as PC banking. Online banking is another term used for Internet banking. Both share the similar meaning. Internet banking or online banking is defined as the use of Internet as a remote delivery channel of banking system services via the WWW. This system enable customers to access their accounts and general information of bank products and services 24 hours a day and 7 days a week through PC or other intelligent device using web browser software, such as Netscape Navigator or Microsoft internet Explorer. On the other hand, PC banking is defined as a home banking whereby consumers supplied with a financial software package on disks, allowing consumers to fill in details offline and then to send them into the bank over the bank's private network. Unlike PC banking, Internet banking or online banking does not require proprietary software or access to a private network. Internet banking allows consumers the ability to perform common banking transactions over the internet, at anywhere and anytime at consumers' freedom.

Currently, there are three (3) basic kinds of Internet banking services being employed in the marketplace, respectively the informational, communicative and transactional. Internet banking allows customer to have direct access to their financial information and undertake financial transactions without the hassle of going to the bank. A.C.Nielsen (2001) found that Internet banking is expanding in many Asian countries including India, Pakistan, Bangladesh, South Korea, Hong Kong, Singapore, China and Taiwan. Although still at developing stage, Malaysia and Thailand have successfully followed worldwide trends in implementing selfservice technology via the Internet (Hamid et al 2007).

\section{Why Study Bangladesh Banking Sector}

The banking sector of Bangladesh is relatively large to the size of its economy compare to other developing countries. The total size of this sector is at 26.54 percent of GDP while the total size of the non-bank financial sector is only 3.22 percent of GDP. The banking sector of Bangladesh comprises of four categories of scheduled banks (Schedule Bank Statistics, 2008). Banks are grouped into four categories (a) State- Owned banks, (b) Islamic banks, (c) Foreign banks and (d) Private banks. However, severe data limitations compel us to confine our attention to only 20 Bangladeshi banks in the database from the Economic Census for Enterprises for which we obtain sufficient balance sheets and income statements data on those banks in the country conducted by the Bangladesh Bank in 2001-2007.

\section{Objectives Of The Study}

The main objective of the study is to critically examine the online banking system and its applications of the some selected private commercial banks in Bangladesh.

To achieve the main objective, the study highlights the following specific objectives:

1. To examine the adoption of online banking facilities in Bangladesh

2. To identify major components of online banking and their applications,

3. To know the main online banking services offered by the selected banks,

4. To assess the customer satisfaction on online banking services, and

5. To identifying the major problems of online banking service in selected banks. 


\section{Sampling Design:}

\section{Methodology}

The sample for the study has been selected from the list of companies listed in Dhaka Stock Exchange (DSC). The sample size has been limited to a total number of 10 Private Commercial Bank (PCBs) namely Arab-Bangladesh Bank Limited, Bank Asia Limited, The City Bank Limited, BRAC Bank Limited, Dhaka Bank Limited, Dutch-Bangla Bank Limited, Eastern Bank Limited, IFIC Bank Limited, Mercantile Bank Limited, and One Bank Limited, selecting them on the basis of purposive sampling. The purposive sampling has been used for the easy access of the researchers to the requisite primary and secondary data. In order to gather the requisite primary data, a total number of 50 respondents ( 25 big and 25 moderate), are taken from each of the selected banks, they have also been selected purposively for the easy and smooth collection of data.

\section{Methods of Data Collection and Analysis}

The major secondary data used for the study is adoption of online banking, online banking services provide by selected banks. These data were collected from the publicly web side and annual reports of the selected banks by the researchers themselves.

The main primary data used for study have been the customers' satisfaction on online banking offered by selected banks and the problems associated to achieving the satisfaction. All these data were collected using both open end and close end questionnaire from the respondent on the basis of direct interview method.

The study used both descriptive and inferential statistics in analyzing the data. Also, simple frequency counts, percentages and the weighted average score (WAS) were used in the data analysis in order to make this study more analytical and informative.

\section{Literature Review}

In Bangladesh, online banking is increasing continuously but the online banking system still not up to the mark compare to the other developing countries like Malaysia, Thailand, India and so on. Moreover, the foreign banks are the pioneers in adopting online banking service in Bangladesh. For this reason, most of the foreign banks are using the online/computerized transaction system and take a comparative advantage with superior technology by attracting customers.

HAMADI Chakib (2010) demonstrates the existence of a causal relationship between perceived quality, satisfaction and commitment in the context of online banking and revealed that the perceived quality heavily influences the commitment of customers and that this effect was direct and not mediated by satisfaction.

Sarma1 and Singh (2010) mainly focused on providing banking services to customers using web with highly secured technology. Implementing technology was the responsibility of management towards the use of biometric technology in internet banking system for risk management of banks regular activities through authentication. Another study, Qureshi et al (2008) conducted their study to evaluate the customer acceptance of online banking. Almost 50\% of the clients shifted from traditional banking to online banking system. The core reason of this transfer is perceived usefulness, security and privacy provided by online banking.

Rahman (2001-2002) observed that issues relating to electronic fund transfer require security, availability, authenticity, non-repudiability and audibility. He suggested for appropriate control and efficient security measures and also for proper utilization of audit trail in the e-commerce system.

Shamsuddoha(2008) argued that in Bangladesh, banking industry is mature to a great extent than earlier period. It has developed superb image in their various activities including electronic banking. Now modern banking services have launched by some multinationals and new local private commercial banks. Electronic banking is one of the most demanded and latest technologies in banking sector.

Ahshan(2009) argued that online transaction would boost the gross domestic product (GDP) growth and thus help Bangladesh achieve the Millennium Development Goals (MDGs). In the era of globalisation, the Internet makes the world smaller and e-commerce facilitates marketing and shopping from home. E-commerce facilitates business with customers over the internet. In e-commerce, customers can buy goods and services over the Internet.

Nyangosi , Arora , Singh (2009) argued that banking through electronic channels has gained increasing popularity in recent years. This system, popularly known as 'e-banking', provides alternatives for faster delivery of banking services to a wide range of customers. The overall result indicates that customers in India and Kenya have developed positive attitudes and they attach much importance to the emergence of e-banking.

Baten and Kamil (2010) revealed that e-banking serves several advantages to Bangladeshi banking sector, however, the study also showed that the Bangladeshi customers had not enough knowledge regarding e-banking which was rendering by banking sector in Bangladesh. 


\section{Findings And Analysis}

\subsection{Examining the adoption of online banking facilities in Bangladesh}

The existing modern and innovative technology driven products and services offered by the online banking system in Bangladesh includes debit card, credit card, automated Teller Machine(ATM) cards such as Master Card, Visa Card, Q-Cash Card, Point of Sales (POS), online services, internet banking, and Society for Worldwide Inter Bank Financial Telecommunication (SWIFT). The debit card allows its holder's 24-hour cash access to his/her savings or current account through ATM and POS terminals and hence its holder enjoys cash withdrawal facility round the clock. Besides, the credit allows its holder 24-hour cash access within the sanctioned limit to his/her credit account through ATM, POS, Merchant shop window, and payment counter. ATM functions as a cash counter of a bank branch that it allows all types of debit card, credit card, Q-cash, visa and other cards for making online transactions. Moreover, POS functions as a receiving desk of cash counter of a bank branch that allows all types of debit card, credit card, Q-cash, Visa and others cards for making payment against products purchased or services rendered at different merchant locations. The online service provides any branch banking facilities to its customer through respective bank online network. Popular current trend of online banking products and functions are: account balance enquiry, fund transfer among the account of the same customer, opening or modifying of term deposit account and similar service. SWIFT is an international network for the bank community that provides instant message transmission services to its member market news and views, and other aspects.

Table 01 shows the trend in technology adoption in the country's banking sector over the period 1998 to 2011.

\begin{tabular}{|l|c|c|c|c|c|c|c|c|c|}
\hline Year & $\begin{array}{l}\text { No. of } \\
\text { Banks }\end{array}$ & $\begin{array}{l}\text { Cr. } \\
\text { Card }\end{array}$ & $\begin{array}{l}\text { Dr. } \\
\text { Card }\end{array}$ & ATM & POS & Internet & Online & SWIFT & Reuter \\
\hline 1998 & 49 & 2 & 0 & 1 & 1 & 0 & 2 & 4 & 7 \\
\hline 1999 & 49 & 3 & 1 & 2 & 3 & 0 & 2 & 11 & 10 \\
\hline 2000 & 49 & 3 & 1 & 2 & 3 & 0 & 4 & 17 & 11 \\
\hline 2001 & 49 & 4 & 4 & 7 & 4 & 1 & 6 & 23 & 15 \\
\hline 2002 & 49 & 4 & 10 & 12 & 5 & 3 & 7 & 30 & 17 \\
\hline 2003 & 49 & 4 & 11 & 14 & 5 & 3 & 16 & 36 & 22 \\
\hline 2004 & 49 & 8 & 15 & 18 & 7 & 7 & 19 & 40 & 24 \\
\hline 2005 & 48 & 12 & 18 & 22 & 10 & 7 & 22 & 41 & 25 \\
\hline 2006 & 48 & 15 & 22 & 26 & 10 & 7 & 29 & 43 & 25 \\
\hline 2007 & 48 & 18 & 27 & 31 & 16 & 11 & 32 & 43 & 26 \\
\hline 2008 & 48 & 19 & 30 & 34 & 24 & 13 & 33 & 43 & 26 \\
\hline 2009 & 48 & 21 & 36 & 36 & 34 & 20 & 36 & 44 & 30 \\
\hline 2010 & 47 & 23 & 39 & 39 & 38 & 36 & 41 & 47 & 36 \\
\hline 2011 & 47 & 29 & 39 & 39 & 39 & 38 & 45 & 47 & 39 \\
\hline
\end{tabular}

Source: Authors Survey

\subsection{Major components of online banking and their applications}

Online banking works by the help of some specific combined procedures. At first, for online banking we need E-document.

\subsubsection{E-document}

Online banking is nothing but the summation of some bytes. On the other hand, it can be said e-sign. Those bytes are stored in computer memory. They can be changed developed and updated and can be built again. For this reason those have an unbreakable security. For this a huge critical techniques are applied. A matter of unfortunate is that a group of hacker can destroy this security. However, the modern banking system is trying to avoid this problem. Those things are written in first in paper, then it input in computer through typing, using light pens, scanning, digital camera etc. if all the branches of the bank are not linked with network, then there will not be any existence of online banking. For baking structure there must be an Online banking network.

\subsubsection{Computerized Banking-}

The word is now on the figure. We can observe the overall condition of the world after switch on the computer. Traditionally, financial institutions eased paper-based system for recording customer account details. The advent of computer technology provided institutions with the ability to automate many of the back office 
tasks and essentially become more efficient. This meant that more time could be devoted to selling product in the branches rather than back office processing of account and transactions.

5.2.3 ATM Card - UB Debit Card is a Chip device consisting of circuit element on single silicon chip. The Card a complex circuits that process microprocessors with a single chips that contain the complete arithmetic and logic unit of computers. It provided for Banks' customers to perform balance inquiry, mini statement and cash withdrawal as well as transfers through the use of Automated Teller Machines. This green card can also be used for Internet/Online and POS transactions.

5.2.4 Chip Card - Also known as an integrated circuit (IC) Card. A card containing one or more computers chips or integrated circuits for identification, data storage or special purpose processing used to validate personal identification numbers, authorize purchases, verify account balances and store personal records.

5.2.5 Electronic Data Interchange (EDI) - The transfer of information between organizations in machine readable form.

5.2.6 Internet Banking- This is a product that enables the Bank leverage on the Internet Banking System Module in-built on the new Banking Application (BANKS) implemented by the Bank to serve the Internet Banking needs of the Bank's customers.

5.2.7 Mobile Banking - This is a product that offers Customers of a Bank to access services as you go. Customer can make their transactions anywhere such as account balance, transaction enquiries, stop checks, and other customer's service instructions, Balance Inquiry, Account Verification, Bill Payment, Electronic fund transfer, Account Balances, updates and history, Customer service via mobile, Transfer between accounts etc.

5.2.8 Point Of Sale (POS) Machine - A Point-of-Sale machine is the payment device that allows credit/debit cardholders make payments at sales/purchase outlets. It allowed customers to perform the following services Retail Payments, Cashless Payments, Cash Back Balance Inquiry, Airtime Vending, Loyalty Redemption, Printing mini statement etc.

5.2.9 SWIFT-SWIFT stands for Society for Worldwide Inter-Bank Financial Telecommunication. SWIFT is members owned cooperative which provides a fast and accurate communication network for financial transactions such as letter of credit, fund transfer etc. by becoming a number of SWIFT, the bank will open up possibilities for uninterrupted connectivity with over thousands of institutions in about 200 countries around the world.

5.2.10 Smart Card - A Card with a computer chip embedded, on which financial health, educational, and security information can be stored and processed.

5.2.11 Credit Card -Credit card sorted by credit card features. Many credit card carry extra features from mileage rewards and discounts to low or no fee balance transfers, fraud protection and more. With the help of credit card one can withdraw his money, uses for transaction purpose. It has a specific limit up to how much one can withdraw from the card. After the end of the month within a specific date cardholder has to pay to bank. Now it is widely used in our country.

5.2.12 Q-cash -The Q-cash is a self service automated network that services all banking needs. It is shared Qcash consortium which has ten banks within a network. This is the largest ATM network in the country.

5.2.13 Transaction Alert - Our customers carry out debit/credit transactions on their accounts and the need to keep track of these transactions prompted the creation of the alert system by the Bank to notify customers of those transactions. The alert system also serves as notification system to reach out to customers when necessary information need to be communicated.

5.2.14 Western Union Money Transfer (WUMT) - Western union Money transfer is a product that allowed people with relatives in Diaspora who may be remitting money home for family up-keep, Project financing, School fees etc. Nigerian Communities known for having their siblings gainfully employed in other parts of the world are idle markets for Western Union Money Transfer. 


\subsection{AVAILABILITY OF INTERNET BANKING FEATURES}

The primary factor determining the level of demand for online banking will be 'connectivity'--the number of people connected to the Internet. Online banking is going to one of the most popular services utilized by Bangladeshi surfers. The following table depicts the popular online banking services provided by Bangladeshi banks.

Table-2: types of services offered by banks in bangladah

\begin{tabular}{|c|c|c|c|c|c|c|c|c|c|c|}
\hline $\begin{array}{c}\text { INTERNET BANKING SERVICES AND } \\
\text { FEATURES }\end{array}$ & $\begin{array}{l}\underset{\sigma}{\varpi} \\
\underset{\sigma}{\sigma}\end{array}$ & $\underset{\nabla}{\mathbb{D}}$ & $\frac{\varpi}{\pi}$ & $\widetilde{\sigma}$ & $\underset{\varpi}{\varpi}$ & $\underset{\varpi}{\underset{\sigma}{\sigma}}$ & $\underset{\sigma}{\mathbb{\sigma}}$ & $\overline{\bar{\Omega}}$ & $\underset{7}{3}$ & $\underset{\sim}{0}$ \\
\hline Checking online $\mathrm{a} / \mathrm{c}$ balances and statements & $\mathrm{Y}$ & $\mathrm{Y}$ & $\mathrm{Y}$ & $\mathrm{Y}$ & $\mathrm{Y}$ & $\mathrm{Y}$ & $\mathrm{Y}$ & $\mathrm{Y}$ & $\mathrm{Y}$ & $\mathrm{Y}$ \\
\hline Fund transfers & $\mathrm{Y}$ & $\mathrm{Y}$ & $\mathrm{Y}$ & $\mathrm{N}$ & $\mathrm{Y}$ & $\mathrm{Y}$ & $\mathrm{Y}$ & $\mathrm{N}$ & $\mathrm{Y}$ & $\mathrm{Y}$ \\
\hline Bill payment & $\mathrm{Y}$ & $\mathrm{Y}$ & $\mathrm{Y}$ & $\mathrm{N}$ & $\mathrm{N}$ & $\mathrm{Y}$ & $\mathrm{Y}$ & $\mathrm{N}$ & $\mathrm{N}$ & $\mathrm{N}$ \\
\hline Manage savings and current $\mathrm{a} / \mathrm{c}$ & $\mathrm{Y}$ & $\mathrm{N}$ & $\mathrm{Y}$ & $\mathrm{N}$ & $\mathrm{Y}$ & $\mathrm{Y}$ & $\mathrm{Y}$ & $\mathrm{Y}$ & $\mathrm{Y}$ & $\mathrm{Y}$ \\
\hline Card service & $\mathrm{Y}$ & $\mathrm{Y}$ & $\mathrm{Y}$ & $\mathrm{Y}$ & $\mathrm{Y}$ & $\mathrm{Y}$ & $\mathrm{Y}$ & $\mathrm{Y}$ & $\mathrm{Y}$ & $\mathrm{Y}$ \\
\hline Order cheque and books request & $\mathrm{Y}$ & $\mathrm{Y}$ & $\mathrm{Y}$ & $\mathrm{Y}$ & $\mathrm{Y}$ & $\mathrm{Y}$ & $\mathrm{Y}$ & $\mathrm{Y}$ & $\mathrm{Y}$ & $\mathrm{Y}$ \\
\hline Inquiry Exchange Rate & $\mathrm{Y}$ & $\mathrm{Y}$ & $\mathrm{N}$ & $\mathrm{N}$ & $\mathrm{Y}$ & $\mathrm{Y}$ & $\mathrm{N}$ & $\mathrm{N}$ & $\mathrm{N}$ & $\mathrm{N}$ \\
\hline Request for stop cheque payments & $\mathrm{Y}$ & $\mathrm{N}$ & $\mathrm{Y}$ & $\mathrm{Y}$ & $\mathrm{Y}$ & $\mathrm{Y}$ & $\mathrm{Y}$ & $\mathrm{Y}$ & $\mathrm{Y}$ & $\mathrm{Y}$ \\
\hline Fixed deposit placement & $\mathrm{N}$ & $\mathrm{N}$ & $\mathrm{Y}$ & $\mathrm{N}$ & $\mathrm{N}$ & $\mathrm{Y}$ & $\mathrm{N}$ & $\mathrm{N}$ & $\mathrm{Y}$ & $\mathrm{N}$ \\
\hline Requesting the bank statement & $\mathrm{Y}$ & $\mathrm{Y}$ & $\mathrm{Y}$ & $\mathrm{Y}$ & $\mathrm{Y}$ & $\mathrm{Y}$ & $\mathrm{Y}$ & $\mathrm{Y}$ & $\mathrm{Y}$ & $\mathrm{Y}$ \\
\hline Corporate Banking & $\mathrm{N}$ & $\mathrm{N}$ & $\mathrm{Y}$ & $\mathrm{N}$ & $\mathrm{Y}$ & $\mathrm{Y}$ & $\mathrm{Y}$ & $\mathrm{N}$ & $\mathrm{N}$ & $\mathrm{N}$ \\
\hline
\end{tabular}

Source: Authors' Survey ( $\mathrm{Y}=$ currently offered the service, $\mathrm{N}=$ service not offered)

Table-2 shows eleven (11) of basic services commonly offered by online/Internet banking institution in Bangladesh namely, View statement and account balances, Fund transfers, Bill payment, Manage savings and current account, Card service, Order cheque and books request, Inquiry Exchange Rate, Stopping cheque, Fixed deposit placement, Requesting the bank statement, and Corporate banking. The results indicate that all the sample banks operated in Bangladesh are currently offering the same standard of services, in term of View statement and account balances, , Card service, Order cheque and books request, and, Requesting the bank statement. Nonetheless, all the sample banks are currently offering service Order cheques and books request except Bank Asia Limited (BAL). Whilst, DBBL is the only banking institution currently offers all the services for their customers. On the other hand, CBL is offering very limited number of online services to their customers. Finally, it can be said that some of the sample banks namely ABBL, BRAC BL, DBBL, EBL are already thrusting forward in providing the wide range of banking services via the online network in Bangladesh.

\subsection{Assessment of the customer satisfaction on online banking services}

In view of high competition in the modern banking industry, it is very essential to improve the quality of the services rendered to the customers by the bankers in order to measure the level of customer satisfaction. The more quality services rendered to the customers, the better the customer satisfaction. This means that the customer satisfaction depends on quality of banking services. Moreover, a bank's growth greatly depends on the quality of services rendered by the banks. Customers and bankers are complementary to each other (Hoque and Ismat, 2000). A bank cannot survive without customers. Customers are the kings to a bank. They are the customers who play the vital role in banking; it is around them that the entire banking operations revolved. It is the customers' money that a bank deals with. Hence, customers demand proper treatment by the bank. Therefore, the bankers should realize that their first and foremost duty is to provide proper services to their customers. Accordingly, the bank's policies, rules, programs, strategies etc. should be formulated and implemented to satisfy the needs of the customers in the most efficient manner (Malyadri, P, 1998).

In order to assess customer satisfaction on online banking services provided by the selected banks, we have surveyed a total number 50 customers ( 25 big and 25 medium) taking five from each of the selected banks. These customers were selected conveniently for smooth and easy collection of data and information. A total number of eleven types of services as mentioned in table- 2 were placed before the respondents in order to rate their level of satisfaction on each of these services. Their responses have been tabulated below: 
Table-3: Assessment of the level of customers' satisfactions

\begin{tabular}{|c|c|c|c|c|c|c|c|}
\hline \multirow[b]{2}{*}{ INTERNET BANKING SERVICES AND FEATURES } & \multicolumn{5}{|c|}{ Rating Scale } & \multirow[b]{2}{*}{ 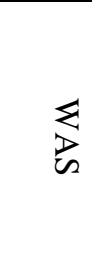 } & \multirow[b]{2}{*}{ 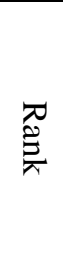 } \\
\hline & 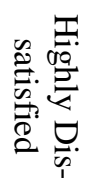 & 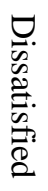 & 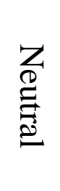 & 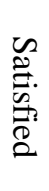 & 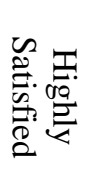 & & \\
\hline Checking of online balances and statements & 0 & 5 & 0 & 35 & 10 & 4.00 & 2 \\
\hline Fund transfers & 0 & 7 & 10 & 25 & 8 & 3.68 & 7 \\
\hline Bill payment & 0 & 4 & 25 & 15 & 6 & 3.46 & 9 \\
\hline Managing savings and current account & 0 & 6 & 6 & 26 & 12 & 3.88 & 4 \\
\hline Card service & 0 & 4 & 0 & 36 & 10 & 4.04 & 1 \\
\hline Order cheque and books request & 0 & 8 & 6 & 24 & 12 & 3.80 & 5 \\
\hline Inquire Exchange Rate & 0 & 4 & 25 & 14 & 7 & 3.48 & 8 \\
\hline Request for stop cheque payments & 0 & 4 & 19 & 15 & 12 & 3.70 & 6 \\
\hline Fixed deposit placement & 0 & 5 & 37 & 5 & 3 & 3.12 & 11 \\
\hline Requesting for the bank statement & 0 & 4 & 6 & 27 & 13 & 3.98 & 3 \\
\hline Corporate Banking & 0 & 3 & 31 & 11 & 5 & 3.36 & 10 \\
\hline
\end{tabular}

Source: Compiled by Authors on the basis of Field Survey

Table-03 reveals the level of customers' satisfaction of the online services provided by selected private commercial banks on the basis of the opinions of the big and moderate customers of Banks operating in Bangladesh. The table depicts that in terms of weighted average score (WAS), Card service occupies the $1^{\text {st }}$ rank with WAS of 4.04 followed by Checking of online balances and statements with 4.00 WAS, Requesting for the bank statement with 3.98 WAS, Managing savings and current account with 3.88 WAS, Order cheque and books request with 3.80 WAS, Request for stop cheque payments with 3.70 WAS, Fund transfers with 3.68 WAS, Inquire Exchange Rate with 3,48 WAS, Bill payment with 3.46 WAS, Corporate Banking with 3.36 WAS and Fixed deposit placement with 3.12 WAS. All these figures signify that the selected customers have been moderately satisfied with all the services since the WAS of the services have been above 3.00.

\subsection{Problems of online banking service in selected banks}

Banks are working hard to get their customer onto using the Internet, where the profit margins are higher than those found in traditional bank. However, some barriers cause customers to anticipate less than expected and they are hesitated on using online network for their banking purposes. Security wise, nasty people lurk around every corner. Hackers, fraudsters, identity thieves and many others would take a chance to get hold of costumer personal details. The problems that online banking services facing towards the competitive world banking in Bangladesh will be better explained on following part of the study.

To find the problems associated with online banking services provided by the selected banks, we have placed an open end question before our respondents in order to mention their problems related in the online banking system. Their responses have been tabulated below:

Table 04: Problems associated with OBS

\begin{tabular}{|l|c|c|c|}
\hline \multicolumn{1}{|c|}{ Problems } & Frequency & Percntage & Rank \\
\hline Unavailability of a backbone network connecting the whole country & 33 & 66 & 8 \\
\hline $\begin{array}{l}\text { Inadequacy of reliable and secured information infrastructure } \\
\text { especially in telecommunication infrastructure }\end{array}$ & 43 & 86 & 5.5 \\
\hline Sluggish ICT penetration in banking sector & 21 & 42 & 9 \\
\hline Insufficient legal and regulatory support for adopting online banking & 47 & 94 & 2.5 \\
\hline Negative attitudes of management & 35 & 70 & 7 \\
\hline Lack of IT resources & 50 & 100 & 1 \\
\hline Lack of knowledge among employees and customers & 47 & 94 & 2.5 \\
\hline Security of the system & 43 & 86 & 5.5 \\
\hline Distrusting the service provider & 45 & 90 & 4 \\
\hline Privacy protection & 17 & 34 & 10 \\
\hline \multicolumn{2}{|r}{} \\
\hline
\end{tabular}


Source: Compiled by Authors on the basis of Field Survey

Table-04 shows 10 (ten) main problems associated with online banking system in private commercial banks in Bangladesh. Among these problems, $100 \%$ of respondents believed that more IT resources have been required for smooth online banking operation in Bangladesh. However, 94\% of respondents have opined in support of insufficient legal and regulatory support for adopting online banking and lack of knowledge among employees and customers, $90 \%$ of respondents have opined in support of distrusting the service provider, $86 \%$ of respondents have opined in support of inadequacy of reliable and secured information infrastructure especially in telecommunication infrastructure and Security of the system, $70 \%$ of respondents opined in support of negative attitudes of management, $66 \%$ of respondents have opined in favor of unavailability of a backbone network connecting the whole country, $42 \%$ of respondents have opined in favor of sluggish ICT penetration in banking sector, and only $34 \%$ of respondents have opined in support of privacy protection. Finally, it can be said that the provider must be more responsive to provide sufficient IT resources and give more emphasize to create IT skilled employees and easy graphical online banking demo in their web sides. Moreover, the government should ensure sufficient legal and regulatory support for adopting online banking to the customers as well as the service provider.

\section{Conclusion}

From the above analyses of the findings it is seen that all the existing private commercial banks operating in Bangladesh have adopted online banking technology for rendering quick and safe services to their customers. Analysis of tabe-3 signifies that the selected customers have been moderately satisfied with all the services as mentioned in the set table. However, there are some problems involved in OBS provided by the selected banks. These problems have been mentioned in table-4. Therefore, it can be concluded that in order to streamline the OBS in the selected banks there is an urgent need to remove those problems as far as practicable. In this respect, the selected banks' authorities as well as Bangladesh Bank have a great role to play. The information generated in the study and its findings may be useful to the researchers, academicians, bankers and policy makers. The academicians interested for further research in this demanding area of the banks may get the findings useful. Again, bankers may also come across the findings of the study while performing their banking jobs for the full satisfaction of the customers. Lastly, the government and policy makers may also use the outcomes of the study while formulating any policy as regards OBS.

\section{Reference}

[1] ACNielsen Online. AC Nielsen Online Taiwan online banking report. Available at: www.acnielsen.com.tw/news.asp?newsID-38. 2001

[2] Ahsan, AFM Mainul :"E-commerce in Bangladesh”, The Financial Express, Bangladesh, January 12, 2009

[3] Alanazi et al " "On the Module of Internet Banking System" JOURNAL OF COMPUTING, 2 (5) 2010,133-143

[4] Baten and Kamil, "E-Banking of Economical Prospects in Bangladesh" Journal of Internet Banking and Commerce, 15 (2 )2010,

[5] Hamill, J. . The internet and international marketing. International Marketing Review, 14(5) 2010,.300-323

[6] Hamid, M. R. A., et al. A comparative analysis of Internet banking in Malaysia and Thailand. Journal of Internet Business(4) 2007,1-19.

[7] Hamadi Chakib, the impact of quality of online banking on customer commitment, IBIMA publishing,2010

[8] Hoque \& Ismat Ara (2000), “Assessment of Customer Services-A Comparative Study of some Nationalized and Private Banks in Bangladesh, Bureau of Business Research, Chittagong University,2000, 2-17.

[9] Kalakota, R., \& Whinston, A. E-commerce: A manager's guide, Addison Wesley, Reading, MA, 1997.

[10] Malydri, P., "Customer services in Commercial Banks:Strategic Maneuvers", Management and Development, Excel Books, New Delhi, 1998, 288.

[11] Nyangosi , Richard, Arora , J.S. ,Singh , Sumanjeet. "The evolution of e-banking: a study of Indian and Kenyan technology awareness", International Journal of Electronic Finance. 3(2), 2009.

[12] Qureshi, T.M., Zafar, M.K and Khan, M.B. (2008). Customer Acceptance of Online Banking in Developing Economies. Journal of Internet Banking and Commerce, 13(1).2008

[13] Rahman,M.Lutfar, "E-Commerce and Concern for E-commerce in Bangladesh", Journal of The Institute of Bankers Bangladesh, .48. 2002

[14] Sarma and Singh, "Internet Banking: Risk Analysis and Applicability of Biometric Technology for Authentication” Int. J. Pure Appl. Sci. Technol., 1(2) (2010), 67-78.

[15] Shamsuddoha, Mohammad (2008). Electronic Banking in Bangladesh, Journal of Business Solutions, 1(2), 2008.

[16] www.bangladesh-bank.org 